\title{
SISTEM INFORMASI MANAJEMEN PENJUALAN, PEMBELIAN DAN INVENTORI KANTOR GM TUPPERWARE
}

\author{
Meme Susilowati $^{1)}$, Ratna Safitri ${ }^{2)}$ \\ 1, 2) Sistem Informasi, Universitas Machung, Villa Puncak Tidak Blok N-1 Malang, Indonesia \\ email : meme.susilowati@machung.ac.id ${ }^{1)}$,321510009@student.machung.ac.id ${ }^{2)}$
}

\begin{abstract}
Abstrak
CV Mitra Karya merupakan perusahaan yang bergerak pada bidang perdagangan dan distribusi produk Tupperware yang melakukan bisnis proses perusahaan secara manual untuk setiap transaksi pembelian, penjualan, hingga pengelolaan stok. Sehingga laporan yang dihasilkan untuk mengetahui hasil bisnis perusahaan masih dihasilkan dari perhitungan manual. Tanpa adanya sistem yang mengelola transaksi bisnis CV Mitra Karya, maka laporan yang dihasilkan tidak akurat dan terpercaya. Dengan adanya SIstem Informasi Manajemen Intenal Perusahaan yang Terintegrasi diharapkan dapat mengelola segala transaksi internal perusahaan yang dapat menghasilkan laporan transaksional dan rekapitulasi bagi pemilik perusahaan. .Sistem dikembangkan dengan metode Three Major Phase, bahasa pemrograman PHP, dan database MySQL. Hasil akhir yang didapat adalah laporan penjualan, pembelian, pengelolaan gudang (stock opname dan kartu stok), serta laporan keuangan berupa pemasukan dan pengeluaran pada perusahaan CV Mitra Karya.
\end{abstract}

\section{Kata Kunci :}

Sistem informasi manajemen, penjualan, pembelian, inventory, manajemen stok.

\begin{abstract}
CV Mitra Karya is a company engaged in the trading and distribution of Tupperware products that do business process companies by manual for every purchase, sale, to stock management transaction. So that the reports generated to find out the company's business results are still produced from manual calculations. Without a system that manages CV Mitra Karya's business transactions, the reports produced will not be accurate and reliable. With the existence of an Integrated Corporate Integrated Management Information System, it is expected to be able to manage all internal company transactions that can produce transactional reports and recapitulation for company owners. . The system was developed with the Three Major Phase method, the PHP programming language, and the MySQL database. The final results obtained are reports on sales, purchases, warehouse management (inventory and stock cards), and financial statements in the form of income and expenditure on the company CV Mitra Karya.
\end{abstract}

Keywords :

Management information system, three major phases, Tupperware, stock management..

\section{PENDAHULUAN}

Perkembangan teknologi informasi dan kemajuan inovasi bisnis memaksa penggerak bisnis untuk mengikuti perkembangan teknologi. Usaha diberbagai bidang untuk mencari inovasi guna menunjang tujuan bisnis. Ditinjau pada perusahaan/bisnis di berbagai bidang tidak terlepas dari tekologi informasi pada perangkat elektronik, baik komputer/laptop, hingga yang telah digunakan melalui piranti pintar seperti tablet maupun telepon pintar. Berdasarkan fenomena yang terjadi pada bisnis diberbagai bidang tidak terkecuali penjualan, dapat digambarkan bahwa usaha pada bisnis perdagangan juga sangat membutuhkan dukungan dari bidang teknologi informasi untuk tetap dapat mengoptimalkan kinerja perusahaan dalam menghadapi persaingan pasar saat ini juga masa mendatang.

Demikian pula dengan CV Mitra Karya merupakan salah satu perusahaan yang melayani penjualan produk Tupperware di Kota Malang, Jawa Timur yang telah berdiri sejak tahun 2007. Berdasarkan keterangan Novalia Mirza sebagai Pemilik, CV Mitra Karya sangat 
URL : https://jurnal.machung.ac.id/index.php/kurawal strategis yaitu berada di ruko di jalur ramai pengendara yang berlokasi di Jalan Raya Kalimosodo, Kota Malang sehingga mudah ditemukan dan menjadi perusahaan yang menjual produk Tupperware.

Permasalahan yang terjadi adalah transaksi yang terjadi setiap hari, minggu, bulan, semakin banyak dan meningkat sehingga proses pencatatan manual yang selama ini berjalan memakan banyak waktu dan tenaga. Transaksi penjualan merupakan ujung tombak dari bisnis di bidang perdagangan, karena hal tersebut merupakan kegiatan operasional rutin pada CV Mitra Karya. Dengan efisiensi dan efektifitas proses bisnis pada bidang manajerial dari CV Mitra Karya, diharapkan dapat meningkatkan produktivitas penjualan dan kualitas pelayanan pada pelanggan CV Mitra Karya yang menjadi member Tupperware. Karena dengan meningkatnya kualitas pelayanan pelanggan akan meningkatkan loyalitas pelanggan untuk tetap bergabung Bersama Tupperware melalui CV Mitra Karya.

Menanggapi permasalahan CV Mitra Karya diatas, maka penulis memberikan sebuah solusi yaitu dengan merancang sebuah aplikasi system informasi berbasis website manajemen internal. Penulis mengangkat permasalahan ini untuk menjadi topik dari proyek Tugas Akhir dengan judul "Rancang Bangun Sistem Informasi Manajemen Perusahaan Penjualan Tupperware Berbasis Web Studi Kasus CV Mitra Karya”. Pada Gambar 1, menjelaskan alur sistem penjualan.

Sedangkan pada gambar 2, menjelaskan alur sistem pembelian. Kemudian yang ketiga membahas tentang alur sistem pengelolaan gudang, yang dijelaskan pada gambar 3 . Perancangan sistem informasi manajemen terdiri dari 3 modul/fungsi besar sesuai pada Gambar 1, 2, dan 3

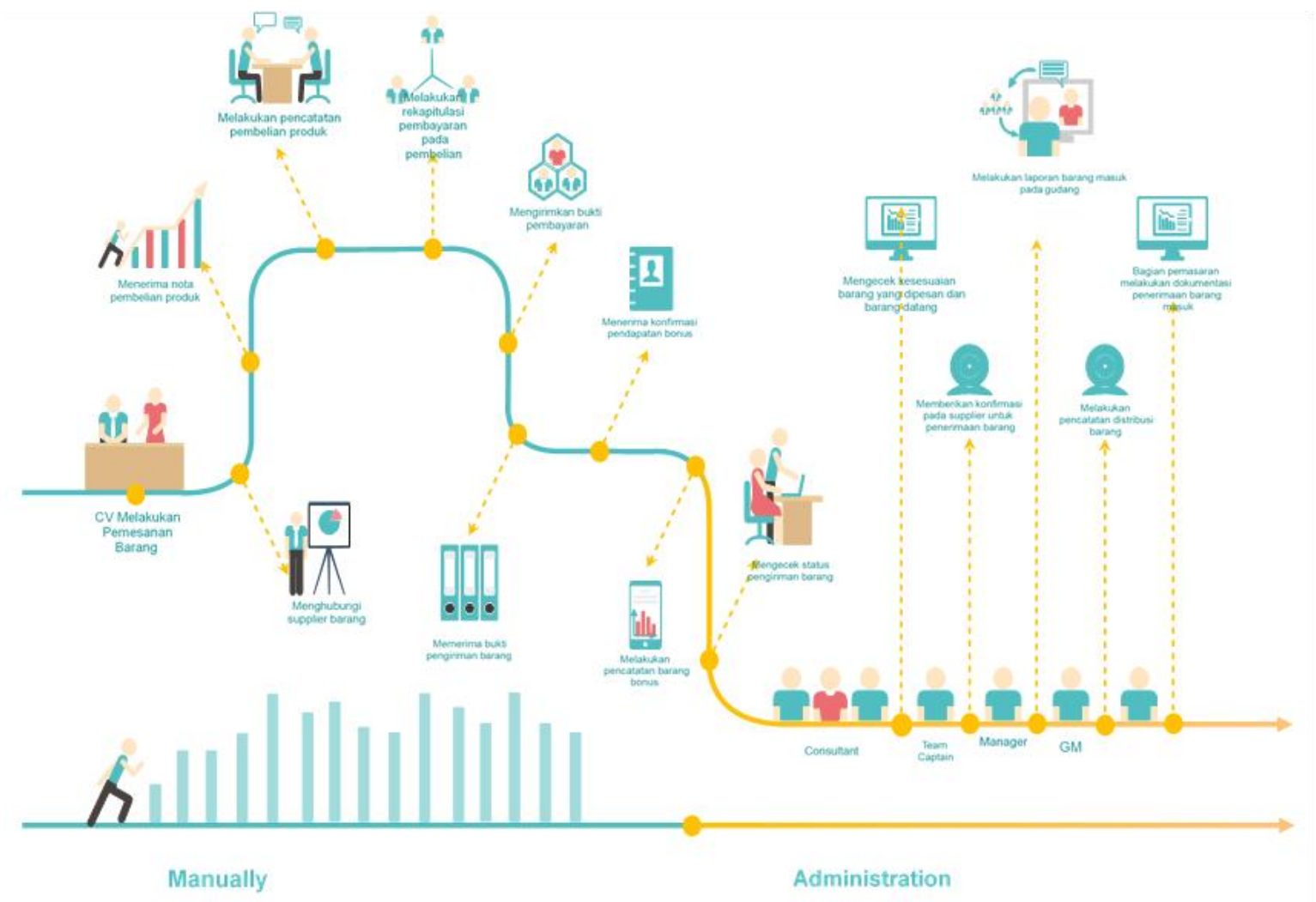

Gambar 1 Workflow Sistem Penjualan 


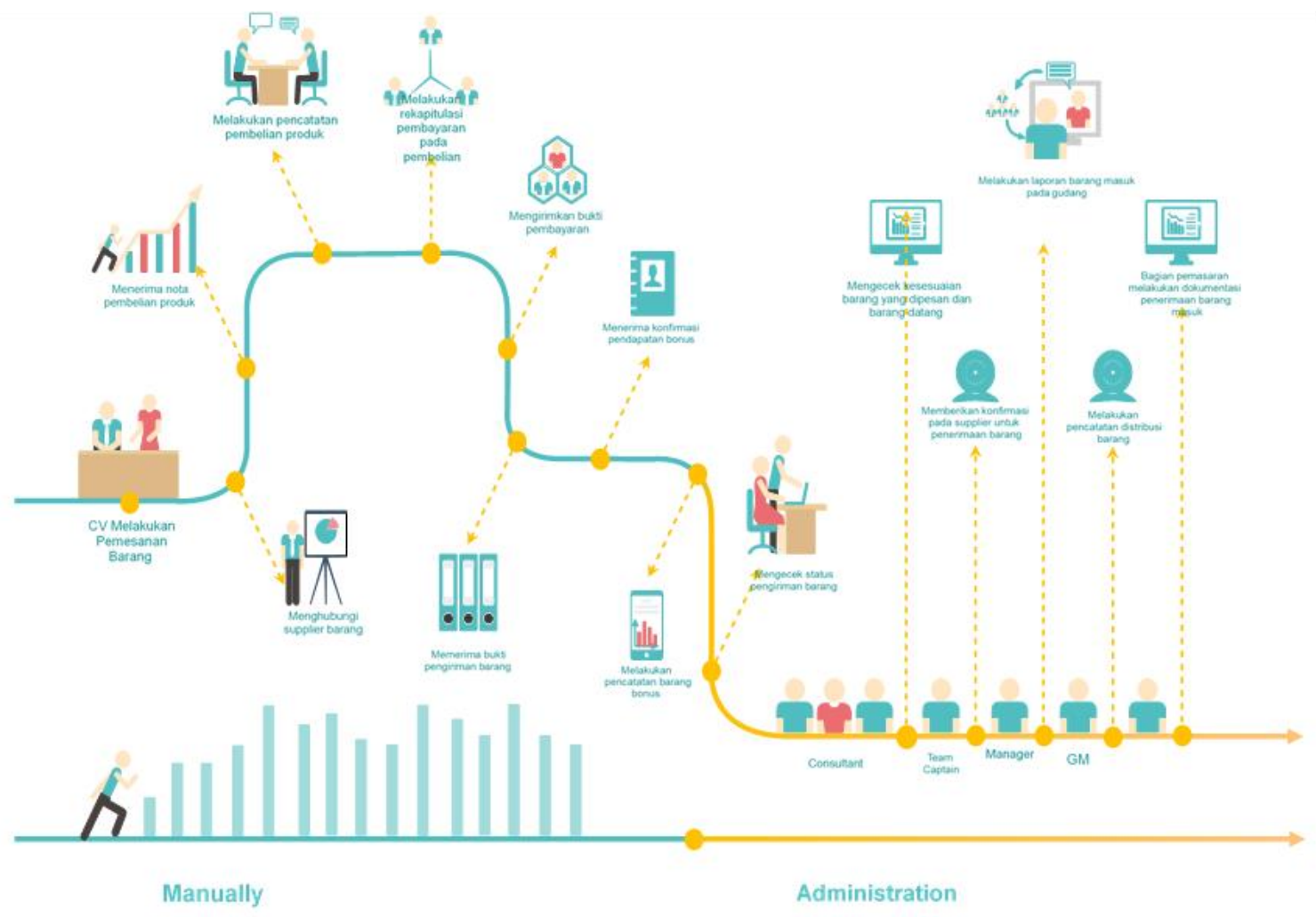

Gambar 2. Workflow Sistem Pembelian

\section{Workflow Gudang \&}

Distribusi

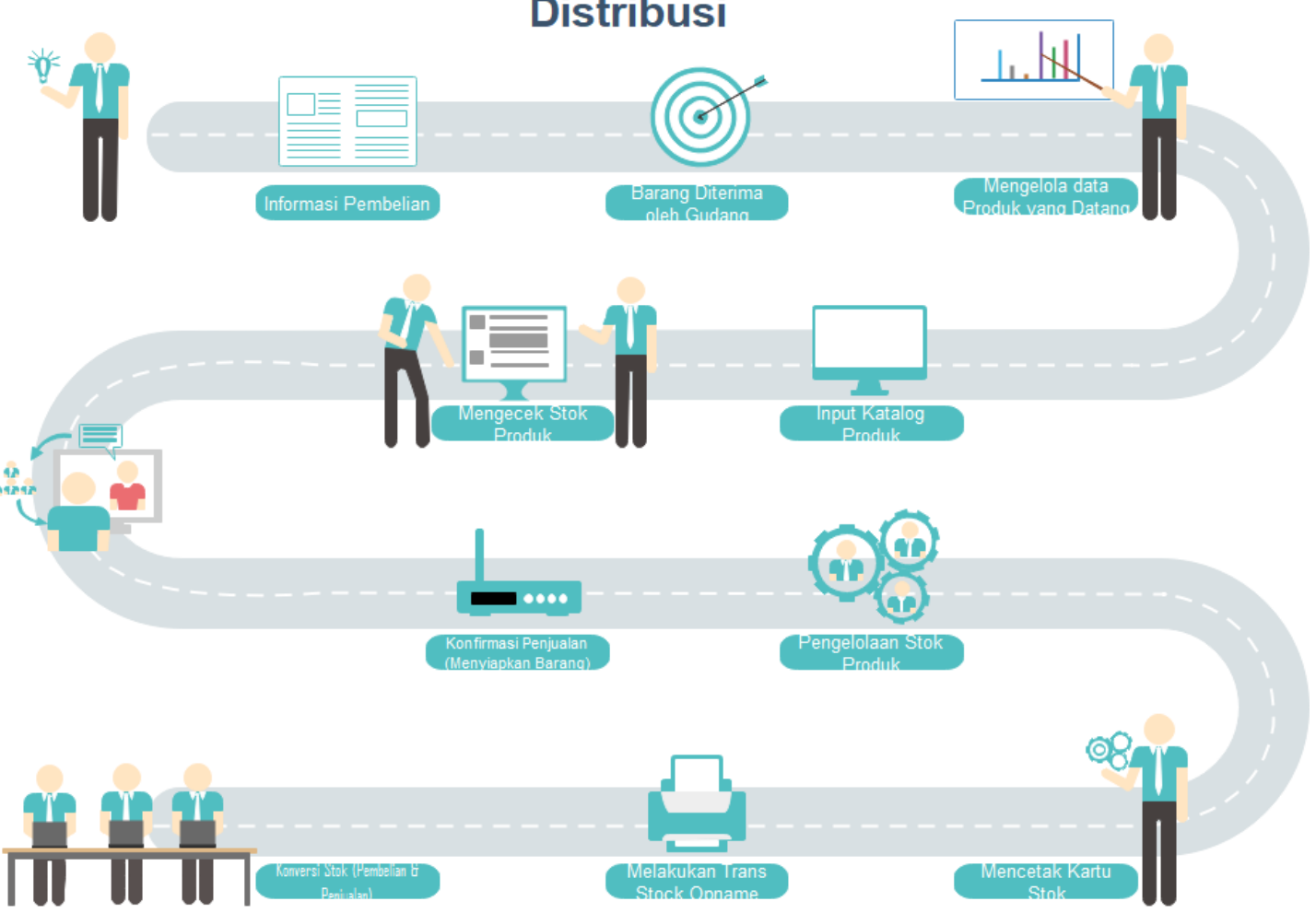

Gambar 3. Workflow Sistem Pengelolaan Gudang 


\subsection{Tinjauan Pustaka}

URL : https://jurnal.machung.ac.id/index.php/kurawal

Penelitian terdahulu yang pertama berjudul "Sistem Informasi Penjualan Berbasis Web Pada PT Era Makmur Cahaya Damai Bekasi” yang disusun mahasiswa Program Studi Sistem Informasi STMIK Nusa Mandiri Jakarta oleh Mikhael Ferdika dan Heri Kuswara (2017). Penelitian ini dibuat secara khusus untuk PT Era Makmur Cahaya Damai Bekasi menggunakan metodologi Waterfall. Fitur dari sistem informasi penjualan tersebut meliputi transaksi penjualan, pembayaran hingga cetak laporan. Sistem ini dikembangkan dengan menggunakan PHP (Hypertext Prepocessor) sebagai bahasa pemrograman dan MySQL sebagai basis data.

Berbeda dengan Sistem Informasi Penjualan Berbasis Web pada PT Era Makmur Cahaya Damai Bekasi, sistem informasi yang dikembangkan tidak mencakup pengelolaan pelanggan dan pemberian bonus pada sistem, serta tidak mencakup Sistem Pembelian, Pengelolaan Stok dan Keuangan. Hal yang menjadi batasan penelitian ini adalah sistem dibangun dan dipergunakan secara online tanpa mengakomodasi bagian internal perusahaan.

Penelitian terdahulu yang ketiga berjudul "Sistem Informasi Inventory Stok Barang pada CV Artha Palembang" yang disusun oleh mahasiswa Universitas Islam Negeri Raden Fatah oleh Rahmawati (2017). Latar belakang dikembangkan sistem informasi ini adalah mengelola proses transaksi penjualan hingga pelanggan melakukan pembayaran dan pengelolaan inventaris berbasis online. Metodologi penelitian ini adalah menggunakan Prototype. PHP (Hypertext Procoessor, dan MySQL sebagai basis data. Hal yang menjadi Batasan penelitian ini adalah sistem dibangun untuk melakukan transaksi penjualan dan inventoy.

Beda dengan Sistem Informasi Inventory Stok Barang pada CV Artha Palembang, sistem informasi tersebut tidak memuat modul dan fungsi untuk mengelola transaksi pembelian yang berkaitan dengan jumlah stok produk pada perusahaan. Hal tersebut yang membedakan sistem informasi yang dikembangkan oleh penulis dengan sistem informasi tersebut. Metode pelaksanaan yang digunakan adalah metode 3 major-phases dari SDLC yang didalamnya terdapat analisis, desain, dan implementasi. Pengembagan dari Sistem Informasi ini menggunakan metode ini karena dirasa paling sesuai dengan kebutuhan perusahaan. Karena metode ini tidak memerlukan waktu lama untuk merancang hingga menerapkan pada system yang dikehendaki.

Sistem Informasi Manajemen atau SIM adalah suatu sistem berbasis komputer yang membuat informasi tersedia bagi para pengguuna yang memiliki kebutuhan serupa. (McLeod dan Schell dalam Zakiyudin: 2011) Sistem informasi Manajemen memiliki beberapa fungsi utama, yaitu:

1) Transaksi Penjualan.

2) Transaksi Pembelian

3) Pengelolaan Gudang yang terdiri dari:

a.Penerimaan Barang.

b.Pengeluaran Barang

c.Pengelolaan Kartu Stok

d.Pengelolaan Stock Opname

e.Penyesuaian Stok (Konversi)

4) Sistem Keuangan Internal, meliputi:

a.Kas Perusahaan

b.Pengeluaran Operasional

5) Laporan Transaksional (reporting).

MySQL adalah salah satu basis data untuk server, jenis basis data ini sangat populer dan digunakan pada banyak website di internet sebagai bank data dari sistem informasi mereka. MySQL menggunakan SQL yang free (tidak perlu membayar untuk menggunakanya) namun 
harus MySQL membayar apabila ingin mendapatkan support langsung dari pihak vendor Oracle (minimal standard edition seharga 2000 dollar per tahun). Keunggulan MySQL yaitu mampu berjalan di berbagai platform, antara lain Linux dan Windows. [3]

Pre-Hypertext Processor (PHP) adalah salah satu bahasa pemrograman yang berjalan dalam sebuah webserver dan berfungsi sebagai pengolah data pada sebuat server. Untuk membuat website yang dinamis dan mudah diubah setiap saat di browser, dibutuhkan sebuah program yang mampu mengolah data dari komputer client atau dari komputer server itu sendiri sehingga mudah dan nyaman untuk disajikan di browser.

PHP adalah salah satu bahasa pemrograman yang handal dan dapat dijalankan di webserver. Dengan menggunakan bahasa pemrograman PHP, sebuah website akan dapat lebih terlihat interaktif, dinamis, dan memungkinkan untuk dipakai membangun sistem informasi. [3]

Responsive Web Design adalah suatu pendekatan yang menganjurkan desain dan pengembangan suatu website hendaknya dapat merespon akan perilaku pengguna dan lingkingan yang mempengaruhi seperti ukuan layar monitor, platform, orientasi yang digunakan pengguna (Knight, 2011).

\section{METODE / ALGORITMA}

Metode pengembangan sistem menggunakan Three Major Phases dengan tiga langkah utama yaitu analisis, desain, dan implementasi. Pada jurnal ini hanya dibahas dua langkah utama saja yaitu tahap analisis dan desain sistem.

1) Analisis, yang terdiri dari:

- Analisa Kebutuhan

- Observasi Bisnis Proses Manajemen Internal (Penjualan, Pembelian, Manajemen

Pelanggan, Gudang, dan Keuangan)

- Survey alur pengelolaan

- Interview pada pihak perusahaan

- Perancangan Sistem Baru

- Mindmap Sistem

Pada tahapan analisis, terdapat 2 kegiatan, yaitu

1. Data gathering : Kegiatan data gathering ditujukan untuk memperoleh data-data yang dibutuhkan untuk pembuatan Sistem Informasi Manajemen CV Mitra Karya Malang.

2. Model data yang ditentukan.

Tools pertama yang dilakukan adalah penelitian mengenai kebutuhan yang sudah ada dan kebutuhan yang dibutuhkan oleh perusahaan "CV Mitra Karya" Tools selanjutnya adalah observasi partisipasi pasif yang bertujuan untuk mengamati tanpa mengganggu proses kegiatan dari "CV Mitra Karya". Hal ini bertujuan untuk mengetahui proses kegiatan tanpa adanya pengaruh dari pihak lain. Tools selanjutnya ialah survey proses pengelolaan internal perusahaan CV Mitra Karya mulai dari proses penjualan, pembelian, sumber daya manusia, gudang, dan keuangan untuk mengetahui informasi-informasi yang lebih dalam lagi.

Setelah didapatkan hasil analisis pada CV Mitra Karya, maka bisa didapatkan data identifikasi kebutuhan sistem sesuai dengan hasil obsevasi atau wawancara untuk menganalisis kebutuhan sehingga didapatkan table kebutuhan seperti pada tabel 1. Setelah didapatkan tabel identifikasi kebutuhan, pada gambar 4, menjelaskan tentang mindmap pengembangan sistem informasi manajemen yang dibuat sesuai dengan kebutuhan dari CV Mitra Karya Malang. 
Tabel 1. Kebutuhan Informasi Pengguna

\begin{tabular}{|c|c|}
\hline Bidang & Kebutuhan Pengguna \\
\hline \multirow{6}{*}{ Gudang } & Mengelola data stok barang \\
\hline & Melakukan validasi barang masuk dari pembelian \\
\hline & Melakukan validasi barang keluar dari penjualan \\
\hline & Mengelola data sirkulasi barang \\
\hline & Mencetak Kartu Stok \\
\hline & Melakukan konversi stock opname \\
\hline \multirow{3}{*}{ Penjualan } & Melakukan transaksi retur da garansi \\
\hline & Melakukan transaksi penjualan dengan garansi \\
\hline & Mengelola data transaksi retur dan garansi \\
\hline \multirow{4}{*}{ Pembelian } & Melakukan transaksi pembelian normal \\
\hline & Melakukan transaksi pembelian bonus \\
\hline & Mengelola data pemasok (supplier) \\
\hline & Mengelola data pembelian produk \\
\hline \multirow{5}{*}{ Keuangan } & Melihat laporan retur dan garansi produk \\
\hline & Melihat laporan pembelian normal dan bonus \\
\hline & Melihat laporan pengeluaran operasional \\
\hline & Melihat laporan sirkulasi kas besar (pemasukan dan pengeluaran) \\
\hline & Melihat laporan pendapatan keuangan $\mathrm{CV}$ \\
\hline
\end{tabular}

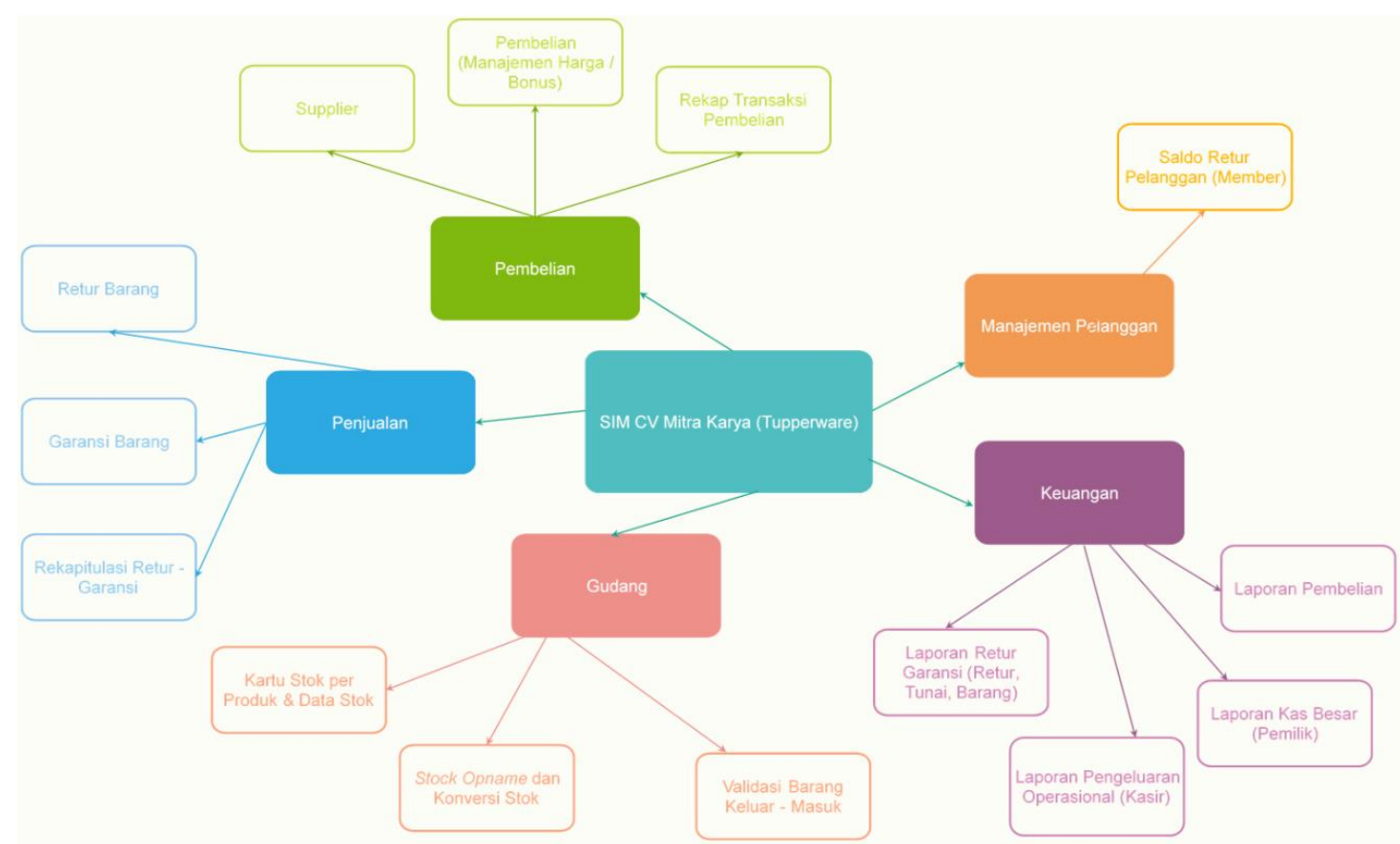

Gambar 4. Mindmap Sistem Informasi Manajemen Terintegrasi 
Setelah didapatkan kebutuhan pengguna dan mindmap pengembangan sistem pada CV Mitra Karya, maka dibentuk desain perancangan hasil analisis seperti berikut.

2) Desain, yang terdiri dari:

- Diagram Use Case untuk Pengelola per Bagian

- Desain Database (Entity Relational Diagram)

- Kamus Data

- Desain Tampilan Input \& Output

Pada jurnal ini dijelaskan Diagram Use Case dan Desain Database (ERD). Diagram Use Case menjelaskan tentang fungsi-fungsi yang dapat diakses oleh actor yang terlibat dengan sistem informasi manajemen pada CV Mitra Karya. Pada gambar 5, menjelaskan tentang Use Case untuk actor pemilik, sedangkan pada gambar 6, menjelaskan tentang Use Case Gudang dan Kasir.

Pada diagram use case actor pemilik, bisa mengakses semua transaksi pada Sistem Informasi Manajemen pada CV Mitra Karya. Berbeda dengan use case untuk bagian gudang dan kasir yang terbatas dapat mengakses transaksi yang berkaitan dengan bagian masing-masing. Pada bagian gudang bisa mengakses transaksi pengelolaan Gudang dan produk pada CV Mitra Karya

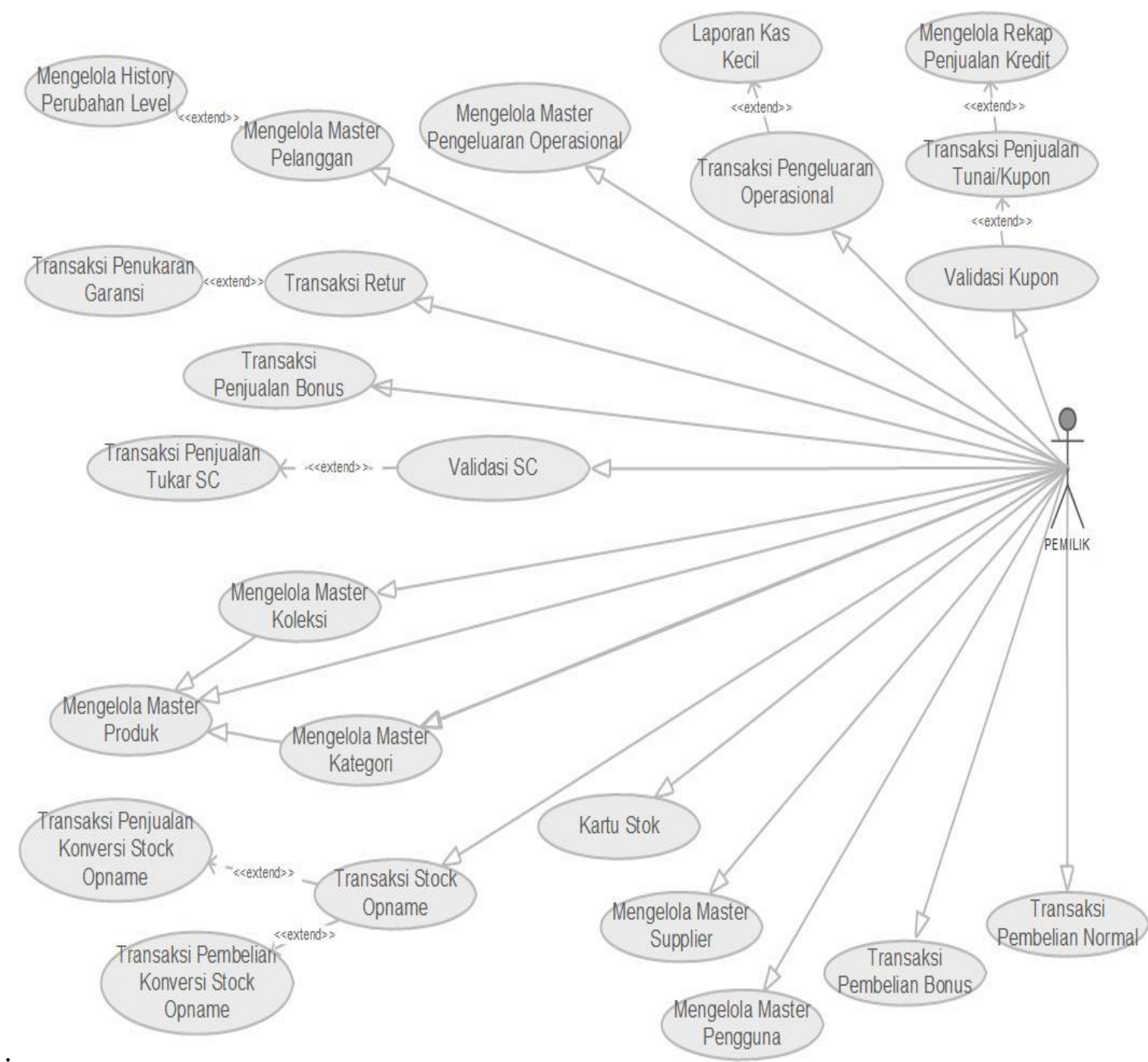

Gambar 5. Diagram Use Case untuk Aktor Pemilik 
URL : https://jurnal.machung.ac.id/index.php/kurawal
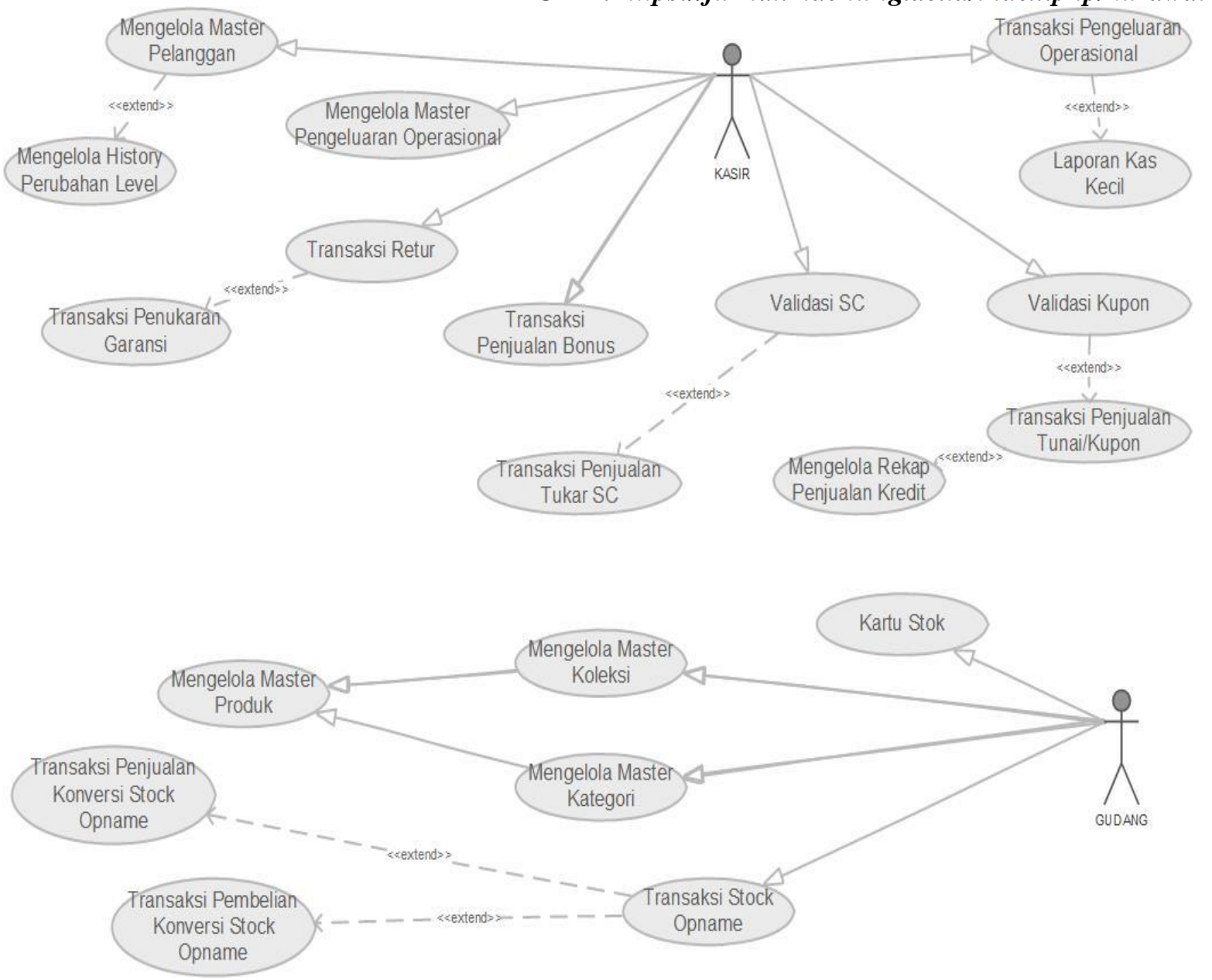

Gambar 6. Diagram Use Case untuk Aktor Gudang \& Kasir

Setelah dibuat desain Diagram Use Case sesuai actor yang terlibat pada sistem, maka dibuat perancangan basis data (ERD), yaitu yang terdapat pada Gambar 7. Perancangan basis data ini merupakan desain basis data yang dibuat untuk mengembangkan Sistem Informasi Manajemen Internal Perusahaan Terintegrasi pada CV Mitra Karya Malang.

\section{HASIL DAN PEMBAHASAN}

Berdasarkan rancangan yang telah dibuat, maka dibangun sistem informasi manajemen internal perusahaan terintegrasi berbasis web pada perusahaan distribusi produk Tupperware dengan tiga hak akses utama, yaitu pemilik (administrator), gudang, dan kasir. Tiap hak akses memiliki tampilan menu yang berbeda. Bagian ini hanya menampilkan hasil dari pengembangan sistem untuk hak akses pemilik, karena semua data dan laporan akuntansi hanya bisa diakses oleh entitas ini. Laporan yang dihasilkan sesuai dengan perancangan yang telah dibuat sebelumnya, yaitu laporan transaksional pembelian, penjualan, retur \& garansi, pengelolaan gudang, dan laporan kas (pemasukan \& pengeluaran).

Pada tahap pembahasan, akan membaas hasil dari perancangan yang dibentuk dalam pengembangan sistem informasi manajemen pada CV Mitra Karya, dan disini akan ditampilkan beberapa hasil pengembangan sistem sesuai dengan rancangan dan desain yang telah dibuat.

Pada gambar 8, tampak menu sitemap pada Sistem Informasi Manajemen Internal Perusahaan Terintegrasi pada CV Mitra Karya Malang. 


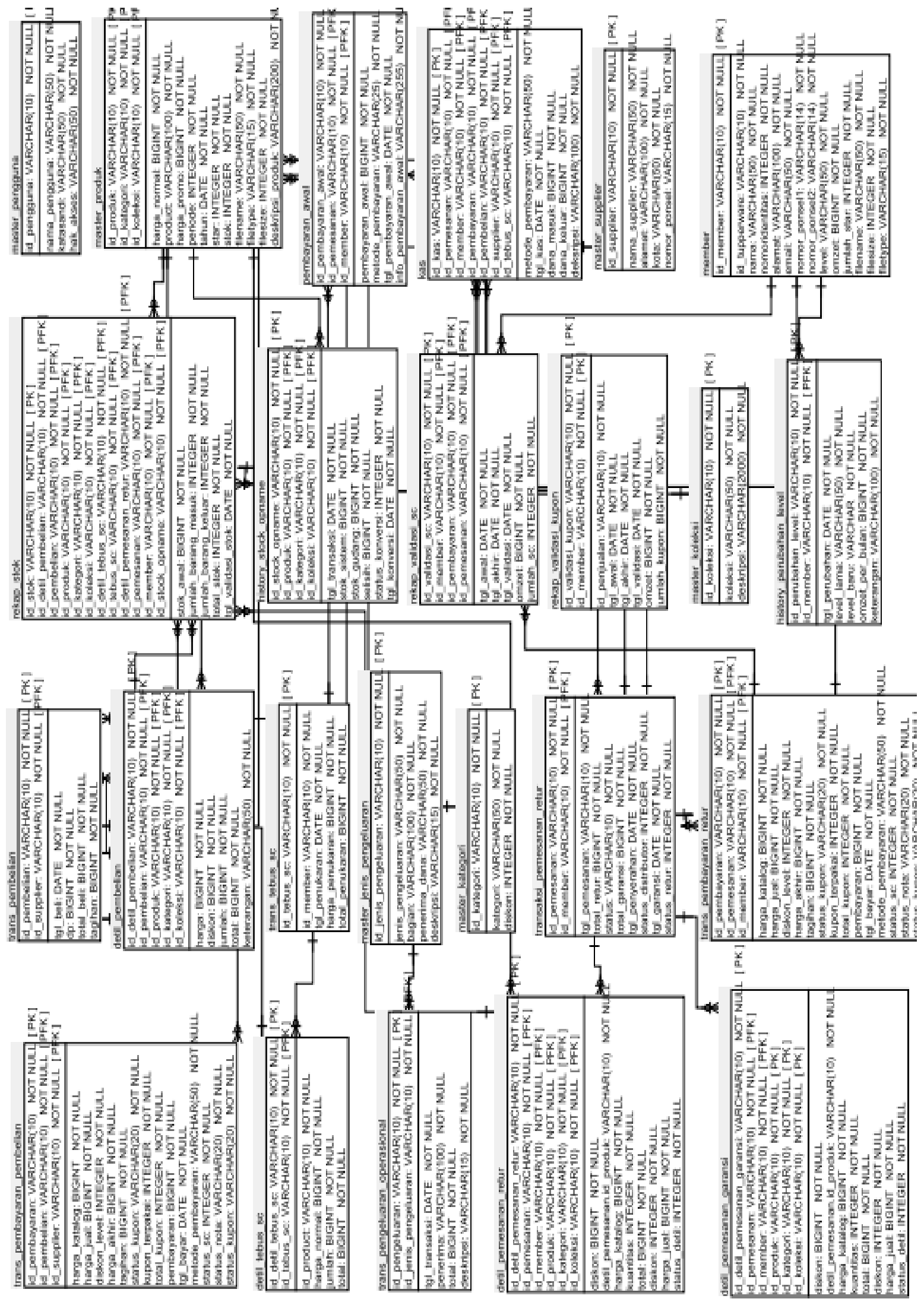

Gambar 7. Desain Basis Data (Entity Relationship Diagram) 
URL : https://jurnal.machung.ac.id/index.php/kurawal

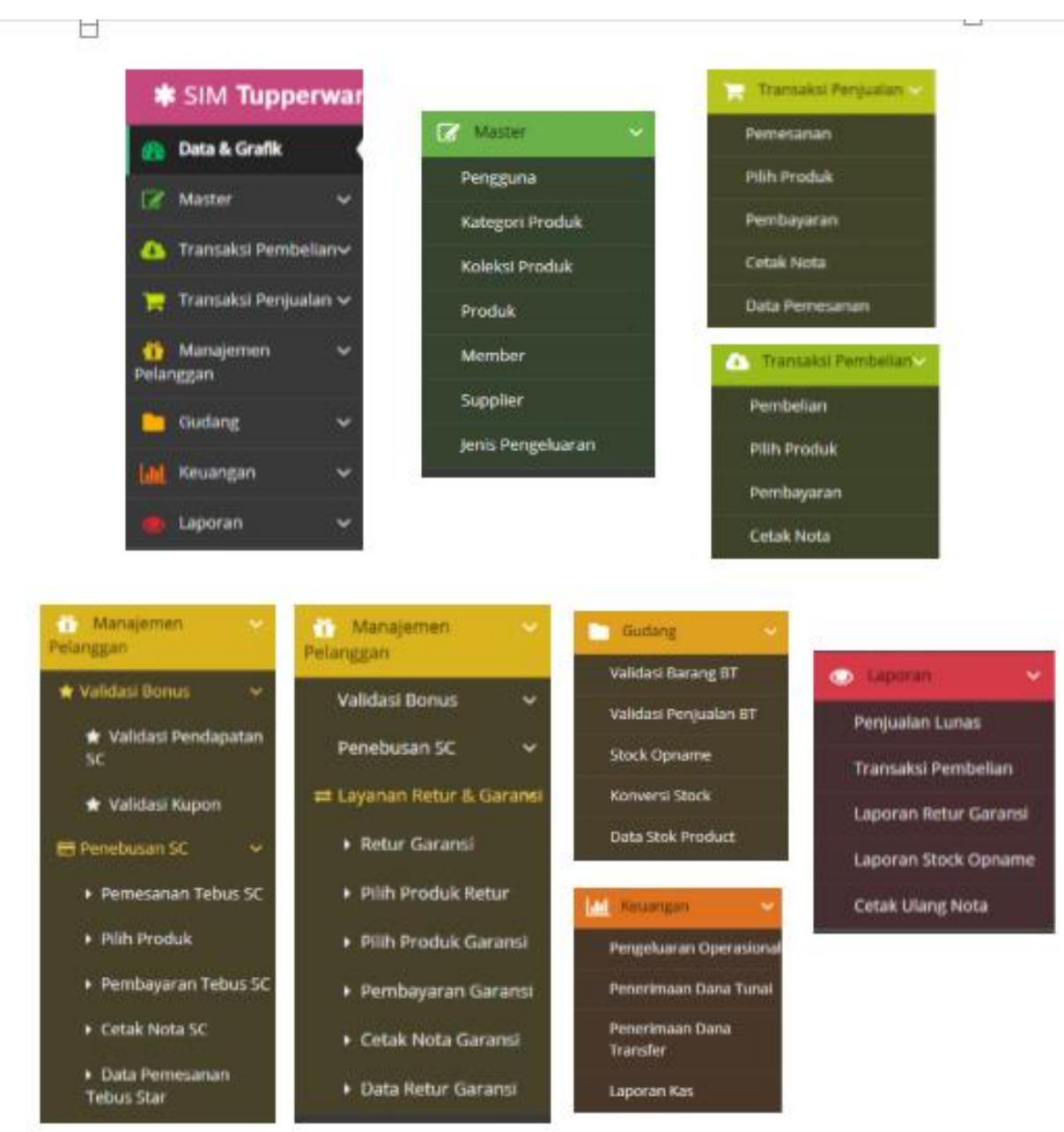

Gambar 8. Sitemap Menu Sistem

Setelah mengetahui sitemap menu pada sistem, berikut adalah beberapa tampilan sistem yang telah dibuat. Sebelum dapat mengetahui sitemap menu pada sistem, pengguna harus melelui halaman login seperti pada gambar 9 .

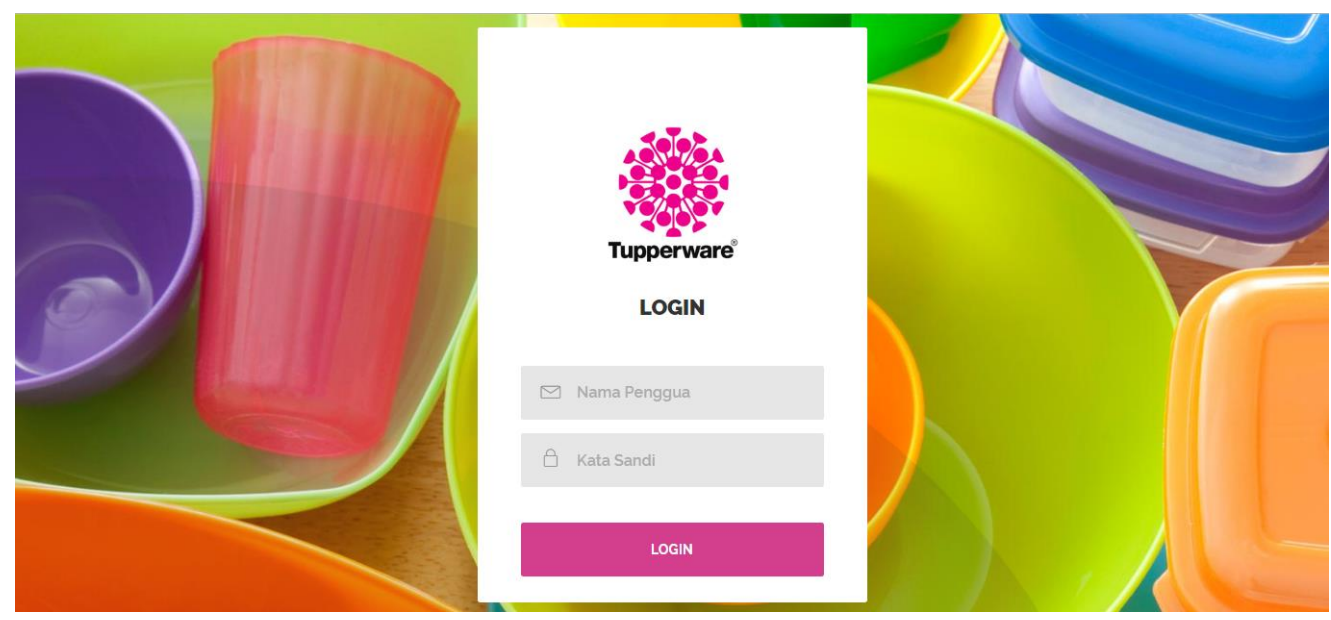

Gambar 9 Tampilan halaman Login 
Setelah berhasil memasuki halaman login dan mengakses nama pengguna dan kata sandi dengan tepat, maka akan dapat masuk pada halaman utama sistem sesuai dengan hak akses pengguna. Pada gambar 10, merupakan tampilan halaman utama yang berisikan data dan grafik yang berkaitan dengan transaksional pada sistem informasi manajemen.

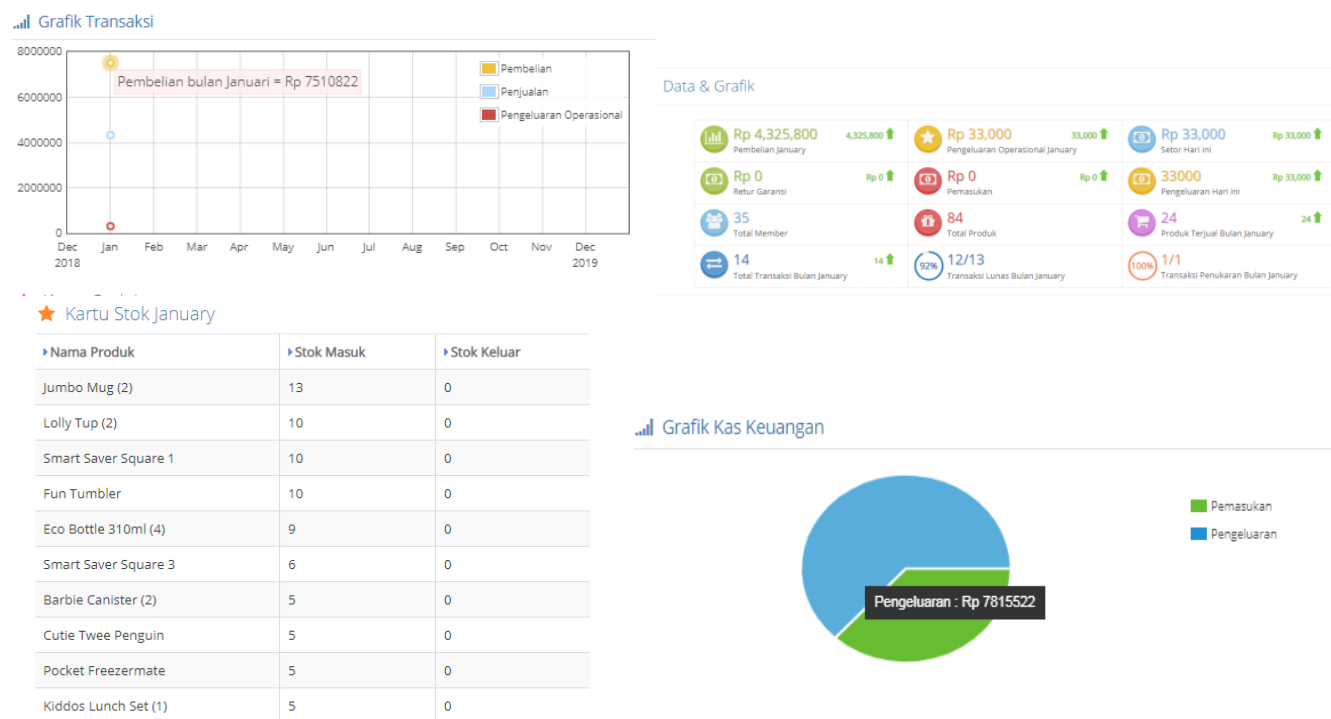

Gambar 10. Tampilan data dan grafik pada sistem informasi manajemen internal

Selain data dan grafik, pada sistem ini juga terdapat pengelolaan master, transaksi dan juga menghasilkan laporan yang terkait dengan bisnis proses perusahaan CV Mitra Karya Malang.

1) Pengelolaan Data Produk

Pengelolaan Data Produk merupakan bagian penting pada sistem informasi manajemen internal perusahaan karena merupakan data master produk yang dipergunakan sebagai acuan produk yang terkait hampir pada semua transaksi perusahaan, seperti pembelian, penjualan, retur \& garansi, bahkan pengelolaan gudang dan stok gudang. Tampilan pengelolaan data produk dijelaskan pada gambar 11.

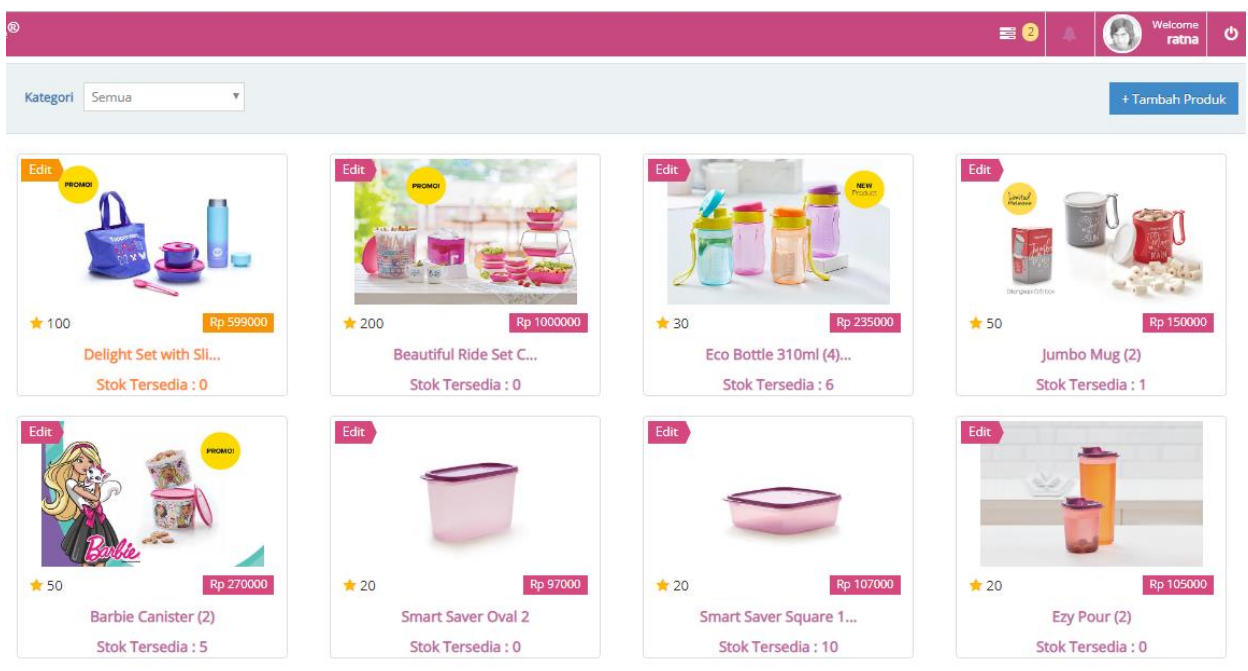

Gambar 11. Pengelolaan Produk Tupperware 
2) Pengelolaan Pengeluaran Operasional

Pengelolaan pengeluaran operasional juga mengelola data master pada jenis pengeluaran dan transaksional pengeluaran operasional. Tampilan pengelolaan operasional dijelaskan pada gambar 12.

\section{Master Jenis Pengeluaran » Input Master Jenis Pengeluaran}

$\begin{aligned} \text { ID Jenis Pengeluaran } & \text { JNP002 } \\ \text { Jenis Pengeluaran } & \text { Beban Listrik PLN } \\ \text { Bagian } & \text { Operasional Ruko } \\ \text { Deskripsi } & \text { Biaya Beban Listrik setiap Bulan }\end{aligned}$

\section{$\checkmark$ Simpan Jenis Pengeluaran $\quad$ Hapus Daftar Jenis Pengeluaran}

Data » Master Jenis Pengeluaran

\begin{tabular}{|c|c|c|c|c|}
\hline ID Jenis Pengeluaran & Jenis Pengeluaran & Bagian & Deskripsi & Modifikasi \\
\hline JNP001 & Beban PDAM Kota Malang & Operasional Bulanan & Penggunaan Air di Ruko & EDIT \\
\hline JNP002 & Beban Listrik PLN & Operasional Ruko & Biaya Beban Listrik setiap Bulan & EDIT \\
\hline JNP003 & Bahan Bakar Motor & Distribusi & Biaya pengeluaran biaya BBM untuk operasional kegiatan perusahaan pada waktu tertentu & EDI \\
\hline
\end{tabular}

Gambar 12. Tampilan Pengelolaan Jenis Pengeluaran
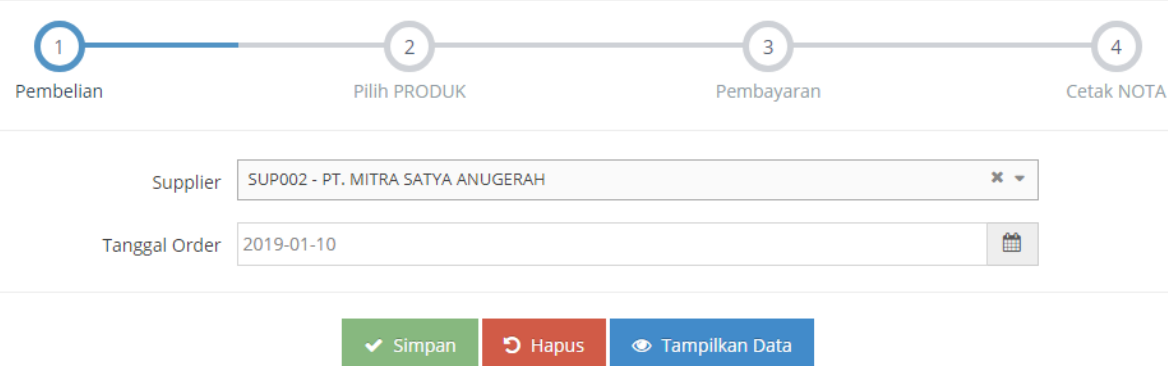

Gambar 13. Tampilkan Daftar Pemasok (Supplier) pada Sistem 


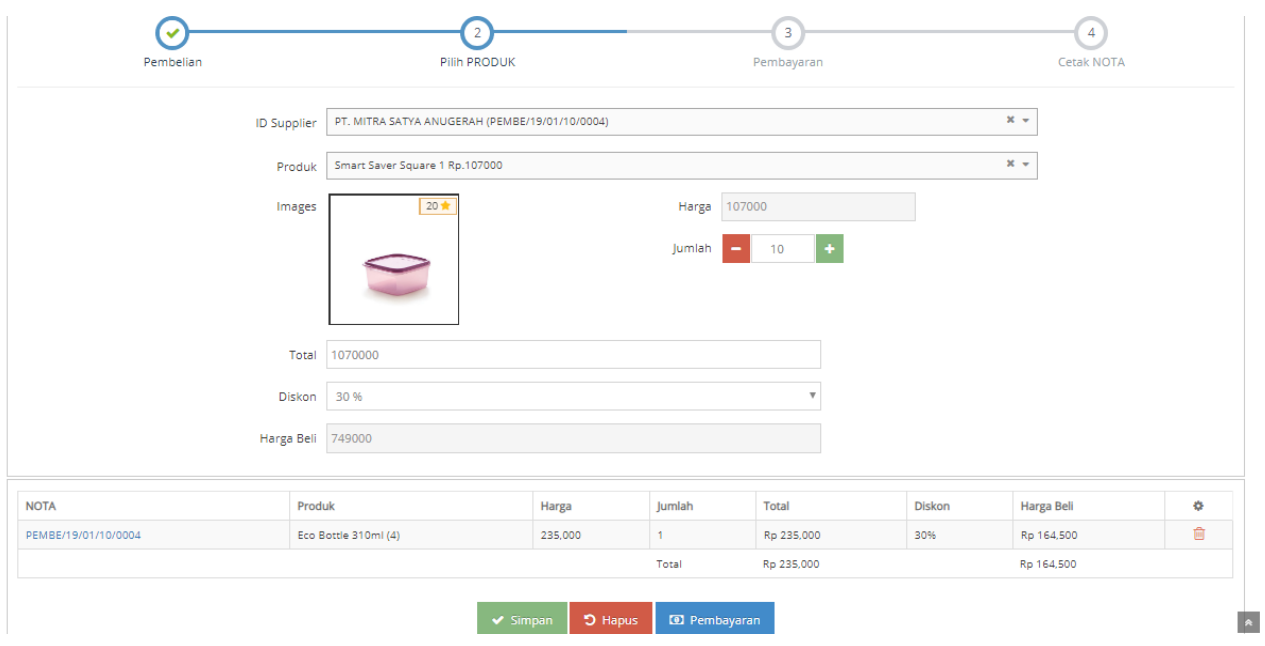

Gambar 14. Tampilkan Daftar Produk yang dipesan pada pemasok

3) Transaksi Pembelian

a) Menambahkan Pembelian

Gambar 13 merupakan halaman tampilan untuk menambahkan transaksi pembelian dengan memilih data pemasok (supplier) dan tanggal pembelian sesuai dengan nota pembeli yang berasal dari distributor / pemasok.
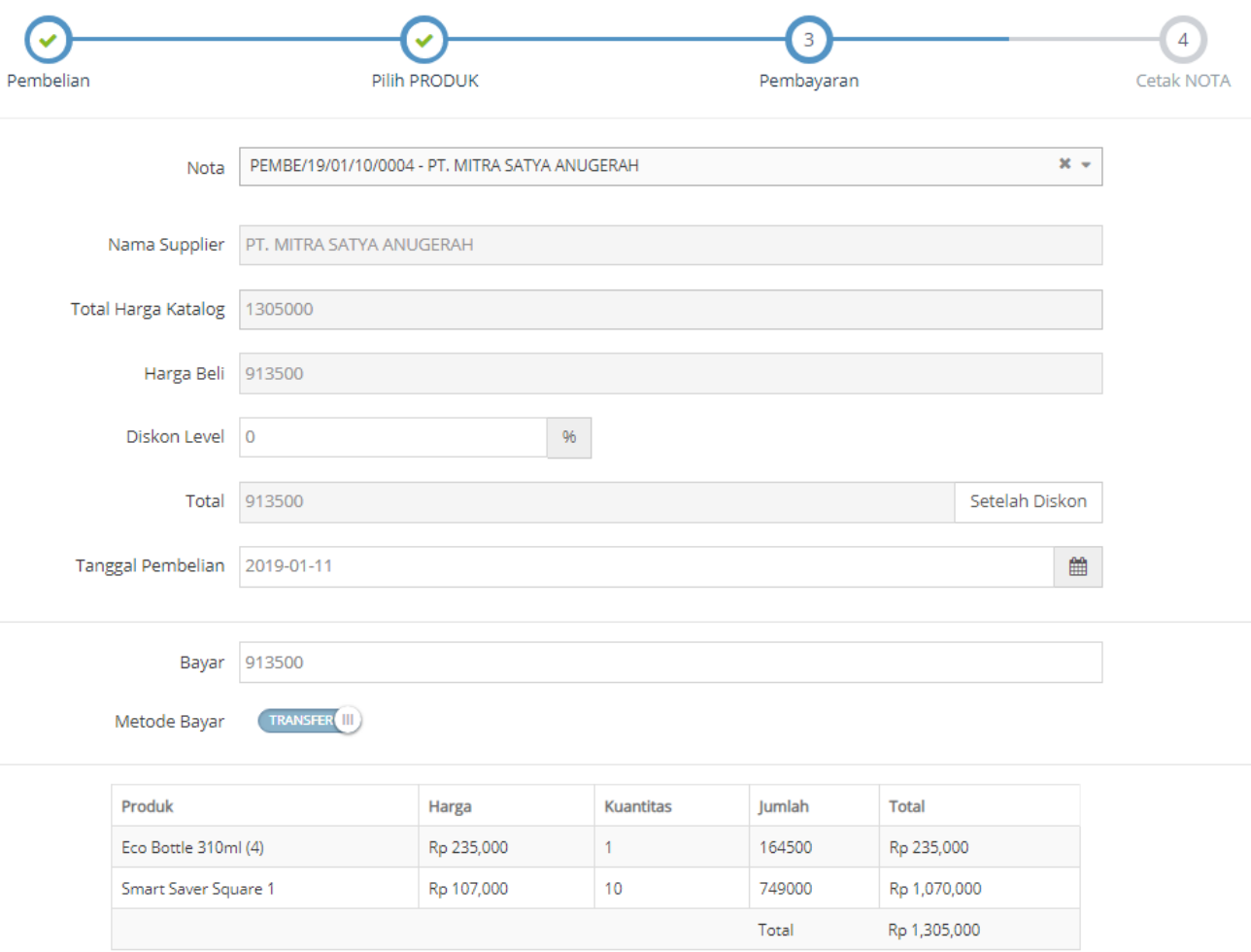

\section{$\checkmark$ Save $\quad$ Reset}

Gambar 15. Tampilkan Halaman Pembayaran Pembelian 
b) Memilih Produk

URL : https://jurnal.machung.ac.id/index.php/kurawal

Gambar 14 merupakan halaman tampilan untuk memilih produk setelah mendaftar pemasok (supplier) pada halaman pembelian, atau memilih nomor nota dan pemasok yang hendak ditambah produk yang dibeli. Pihak Gudang dapat memilih produk yang telah dipesan, dan kuantitas barang kemudian menekan tombol Simpan untuk menyimpan produk, Hapus untuk mengulangi pengisian, dan Pembayaran apabila transaksi Pilih Barang telah selesai dilakukan dan hendak melakukan transaksi pembayaran.

c) Pembayaran Transaksi Pembelian

Gambar 15 merupakan halaman tampilan untuk melakukan transaksi pembayaran pada transaksi pembelian yang telah dilakukan sebelumnya. Kegiatan yang pertama harus dilakukan adalah memastikan bahwa nomor nota dan nama pemasok (supplier) yang dilakukan pembayaran sesuai dengan pembayaran yang telah dilakukan, selanjutnya mengisikan diskon level yang didapatkan sesuai transaksi yang telah dilakukan, tanggal pembayaran, jumlah pembayaran yang telah dibayarkan, dan memilih metode pembayaran, serta memastikan produk yang dibeli.

d) Cetak Nota Pembelian

Gambar 16 merupakan halaman tampilan nota pembelian sebelum dicetak. Nota pembelian dapat diakses apabila transaksi pembelian sudah terselesaikan.

4) Pengelolaan Gudang

a) Validasi Barang Masuk BT (Belum Terima)

> Melakukan Validasi Barang Masuk Belum diterima

Gambar 17 merupakan halaman validasi transaksi pembelian yang telah dilakukan, tetapi produk belum diterima oleh CV kemudian dilakukan konfirmasi bahwa produk yang diterima oleh bagian Gudang berdasarkan nota pembelian yang dilakukan. Validasi dilakukan per produk dari masing-masing transaksi

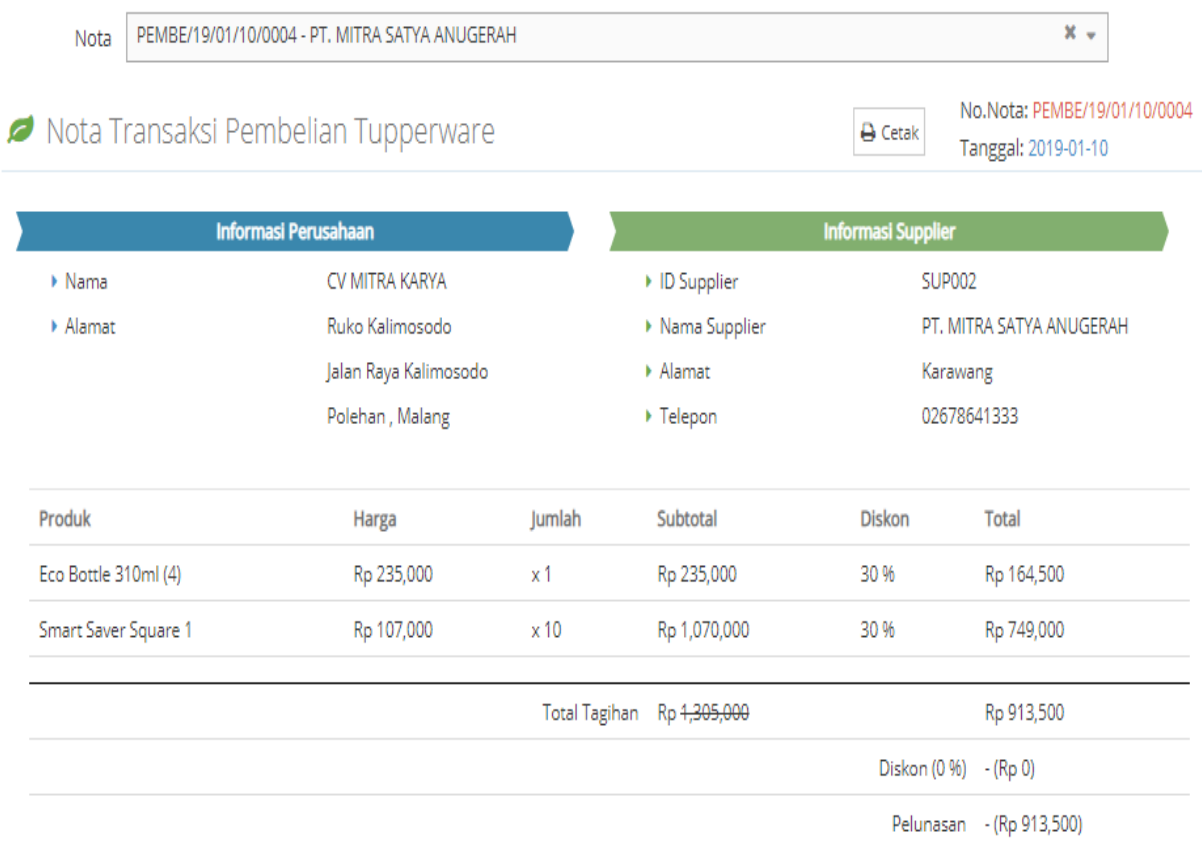

Gambar 16. Tampilan Nota Pembelian 
Validasi Barang Masuk

\begin{tabular}{|c|c|c|c|c|}
\hline Nota Pembelian & Tgl Pembelian & Produk & Kuantitas & \% \\
\hline PEMBE/19/01/10/0004 & 2019-01-10 & Eco Bottle $310 \mathrm{ml}$ (4) & 1 & $\checkmark$ \\
\hline PEMBE/19/01/10/0004 & 2019-01-10 & Smart Saver Square 1 & 10 & $\checkmark$ \\
\hline PEMBE/19/01/1/3/0005 & 2019-01-13 & Smart Saver Square 3 & 1 & $\checkmark$ \\
\hline
\end{tabular}

Gambar 17. Validasi Barang Masuk Belum Diterima

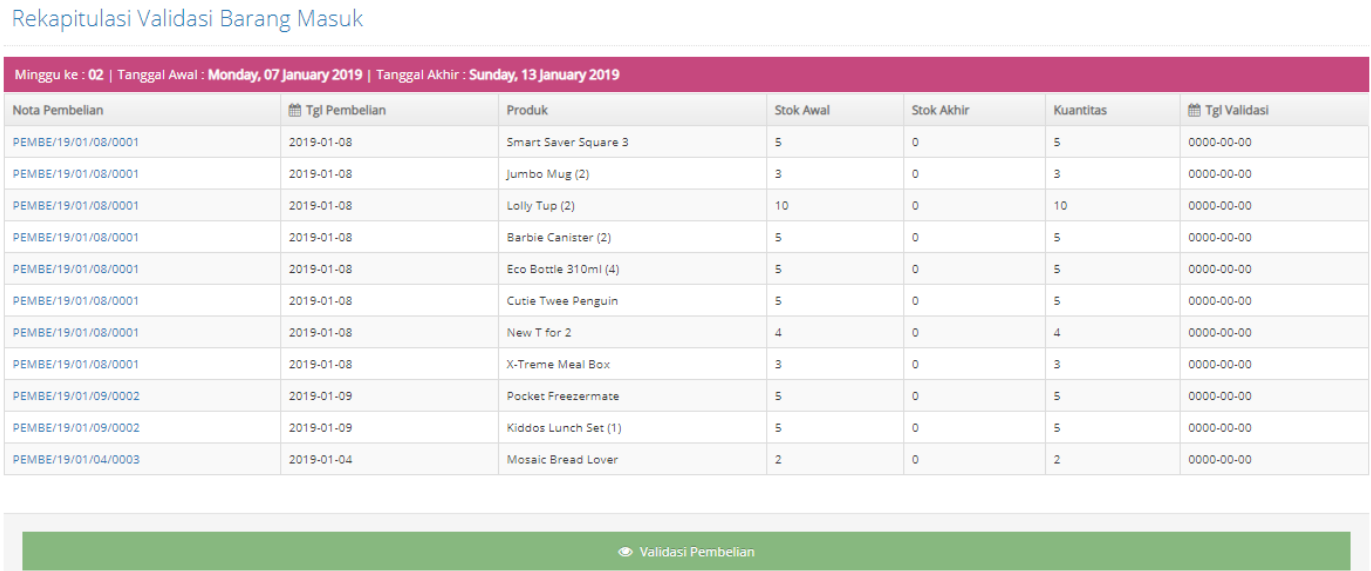

Gambar 18. Rekapitulasi Validasi Barang Masuk Belum Terima

Validasi Barang Keluar

\begin{tabular}{|c|c|c|c|c|}
\hline ID Transaksi & 酋 Tgl Penjualan & Produk & Kuantitas & \% \\
\hline CART1901110002 & 2019-01-11 & Smart Saver Square 3 & 1 & $\checkmark$ \\
\hline
\end{tabular}

Gambar 19. Validasi Barang Keluar BT

Rekapitulasi Validasi Barang Keluar

\begin{tabular}{|c|c|c|c|c|c|c|}
\hline Nota Penjualan & Tgl Transaksi & Produk & Stok Awal & Stok Akhir & Kuantitas & Tgl Validasi \\
\hline ORDER/19/01/11/0001 & 2019-01-11 & Jumbo Mug (2) & 1 & 3 & 2 & $0000-00-00$ \\
\hline ORDER/19/01/13/0002 & 2019-01-13 & Lolly Tup (2) & 1 & 10 & 9 & $0000 \cdot 00 \cdot 00$ \\
\hline
\end{tabular}

Gambar 20. Rekapitulasi Validasi Barang Keluar 
URL : https://jurnal.machung.ac.id/index.php/kurawal

Rekapitulasi Barang Masuk BT (Belum Terima)

Gambar 18 merupakan halaman rekapitulasi validasi transaksi pembelian yang telah dilakukan, untuk memvalidasi produk yang diterima oleh bagian Gudang berdasarkan nota pembelian yang dilakukan. Rekapitulasi atas validasi barang yang masuk dicatat berdasarkan tanggal validasi yang dilakukan.

b) Validasi Barang Keluar BT (Belum Terima)

$>$ Melakukan Validasi Barang Keluar

Gambar 19 merupakan halaman validasi transaksi penjualan normal atau penebusan starchart yang telah lunas dan selesai dilakukan, untuk memvalidasi produk yang dikeluarkan oleh bagian Gudang berdasarkan nota penjualan yang dilakukan. Validasi dilakukan per produk dari masing-masing transaksi, validasi dilakukan untuk mengurangi stok pada masing-masing produk.

$>$ Rekapitulasi Barang Keluar

Gambar 20 merupakan halaman rekapitulasi validasi transaksi penjualan yang telah dilakukan, untuk memvalidasi produk yang diterima oleh bagian Gudang berdasarkan nota penjualan yang dilakukan. Rekapitulasi atas validasi barang yang keluar dicatat berdasarkan tanggal validasi yang dilakukan.
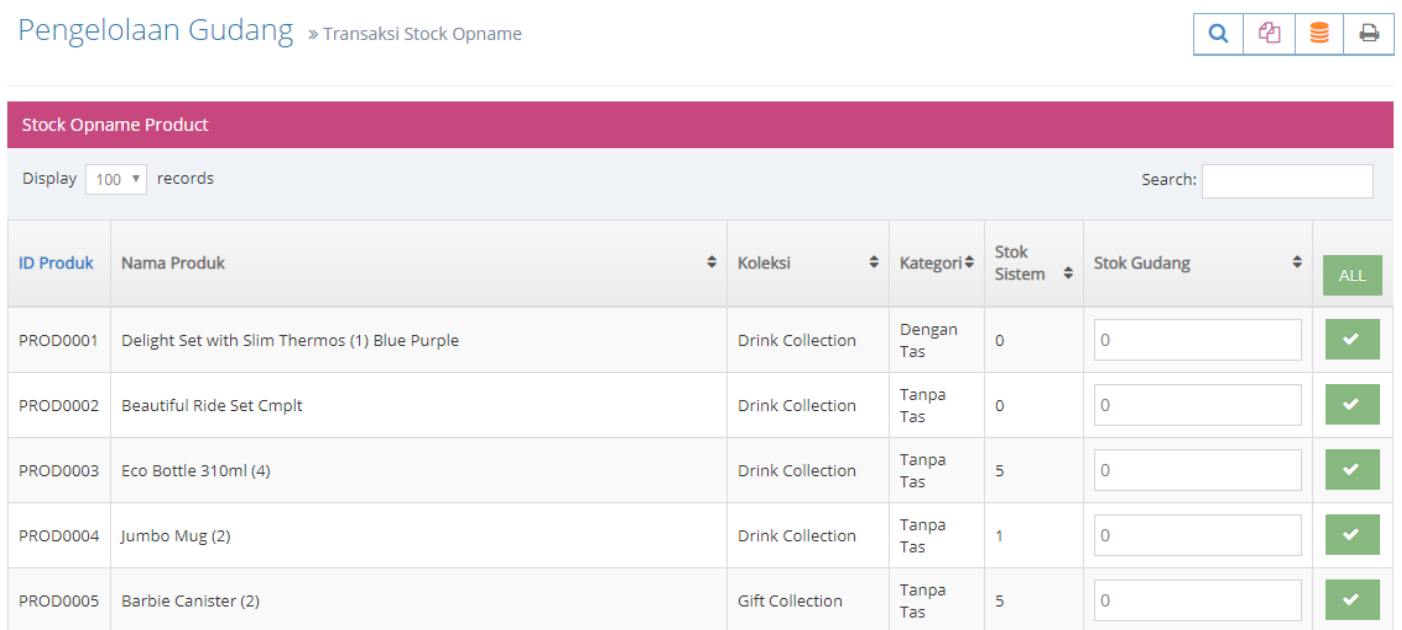

Gambar 21. Transaksi Stock Opname

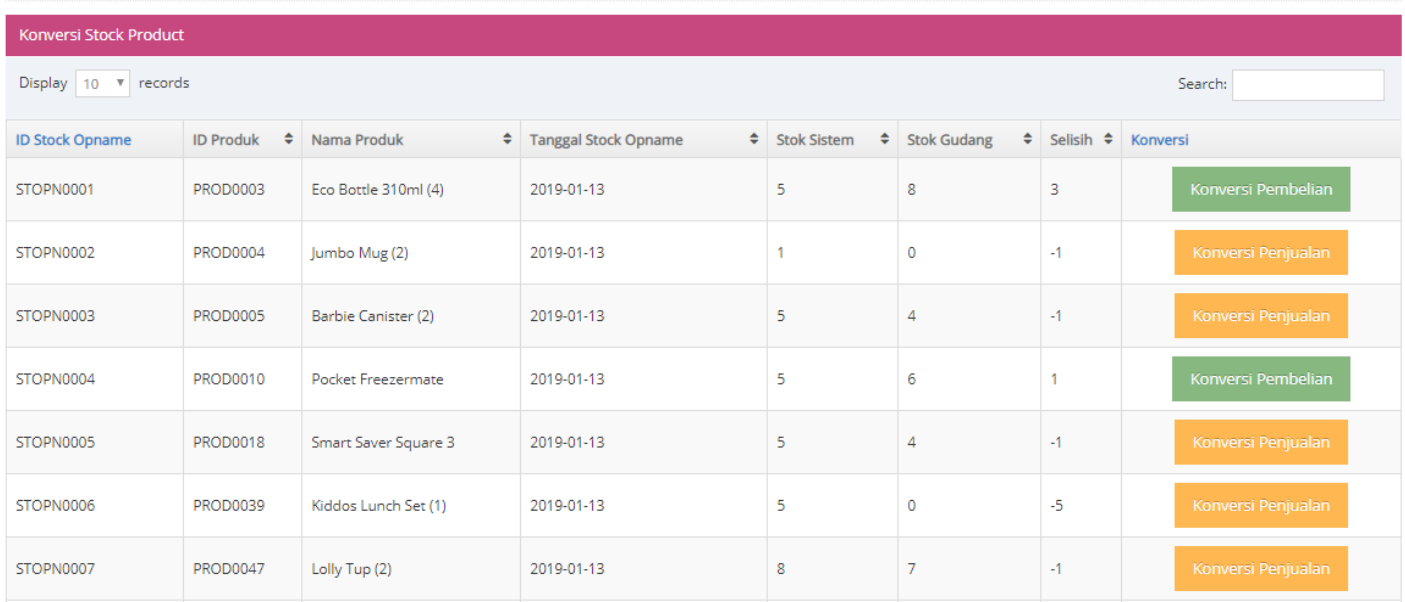

Gambar 22. Transaksi Konversi Stock Barang 
c) Stock Opname

Gambar 21 merupakan halaman transaksi stock opname yang dapat dilakukan bagian Gudang untuk memberikan validasi stok antara stok yang tercatat pada system dan stok yang ada pada kondisi lapangan. Dengan melakukan stock opname maka akan dapat diketahui berapa produk yang belum tercatat pada penjualan (barang keluar) dan pembelian (barang masuk). Validasi dapat dilakukan setiap produk atau dilakukan secara bersamaan pada satu perintah konfirmasi stok secara keseluruhan.

d.) Konversi Stock

Gambar 22 merupakan rekapitulasi hasil stock opname yang dihasilkan, tetapi mendapatkan selisih atau kondisi yang ada pada stok system dan stok Gudang berbeda. Dengan adanya konversi stok, maka stok system dan stok Gudang akan mendapatkan hasil yang seimbang / sama karena akan dilakukan pencatatan pembelian dengan konversi apabila selisih stok Gudang > stok system. Dan sebaliknya aka dilakukan pencatatan penjualan dengan konversi apabila selisih stok Gudang < stok system. Konversi stok aka tercatat pada setiap table yang sama dengan transaksi pembelian atau penjualan pada normalnya karena untuk mengetahui pula keuangannnya.

\begin{tabular}{|c|c|c|c|c|c|}
\hline Filter All & & & & & \\
\hline \multicolumn{5}{|c|}{$\begin{array}{l}\text { Kartu Stok Produk : Eco Bottle } 310 \mathrm{ml}(4) \\
\text { Jumlah Barang Masuk : } 16 \\
\text { Jumlah Barang Keluar : } 8\end{array}$} & @ CETAK \\
\hline PEMB1901250001 & 15 Oct 2018 & 6 & 0 & 6 & \\
\hline CART1901250001 & 18 Oct 2018 & 0 & 1 & 5 & \\
\hline CART1901250002 & 23 Oct 2018 & 0 & 1 & 4 & \\
\hline
\end{tabular}

Gambar 23. Rekapitulasi Kartu Stock

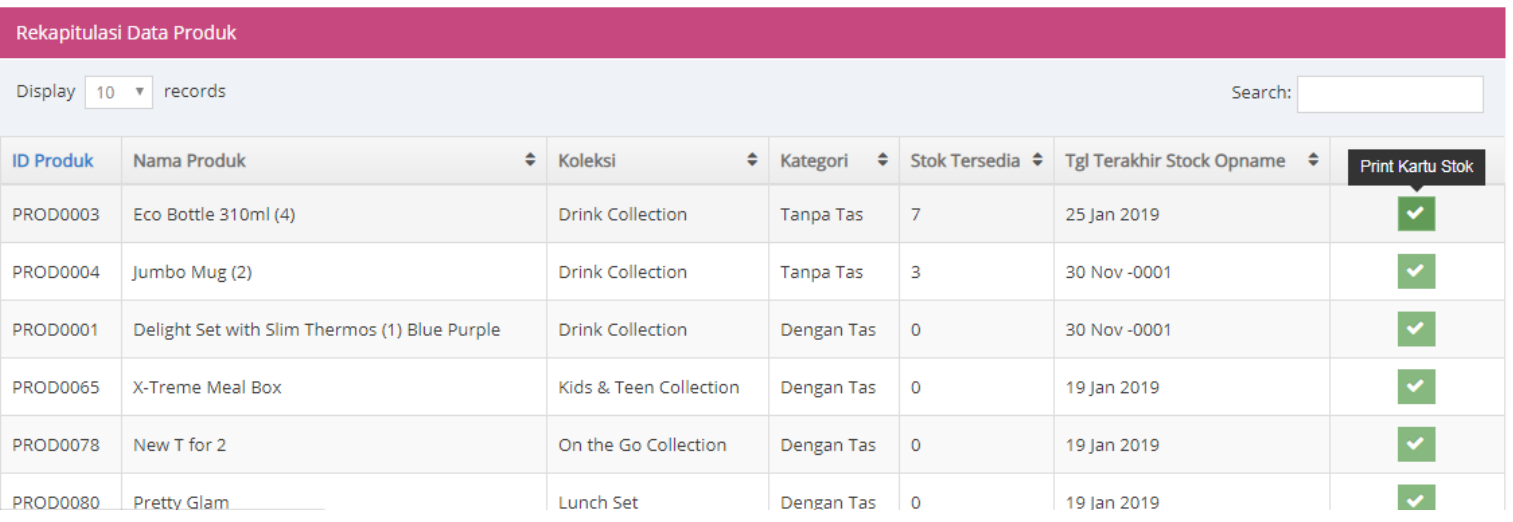

Gambar 24. Data Stok Produk 
e.) Kartu Stock

URL : https://jurnal.machung.ac.id/index.php/kurawal

Gambar 23 merupakan rekapitulasi halaman awal apabila hendak mengakses kartu stok, dengan memilih Menu Gudang, kemudian meng-klik Tombol Print Kartu Stok, maka akan muncul rekapitulasi Kartu Stok sesuai dengan produk yang dipilih. Adapun keterangan pada kartu stok merupakan catatan transaksional pada Sistem Informasi Manajemen Terintegrasi yang tercatat keluar dan masuknya berdasarkan kondisi stok terkini pada tabel master produk.

f.) Rekapitulasi Data Stock Product

Gambar 24 merupakan data stok produk yang tersedia pada saat ini. Stok yang ada merupakan stok system yang telah berkurang dan bertambah berdasarkan setia transaksi pembelian dan transaksi penjualan yang terjadi pada system informasi terintegrasi, serta telah dilakukan validasi oleh bagian gudang.

5. Laporan - laporan

a) Laporan Pengeluaran Operasional

Gambar 25 merupakan laporan pengeluaran operasional yang berasal dari transaksi pengeluaran operasional yang telah ditambahkan dan tersimpan pada table pengeluaran operasional. Pengeluaran yang ada sebelumnya telah ditambahkan pada master jenis pengeluaran, pengeluaran operasional yang dimaksud adalah pengeluaran setiap bulan maupun pengeluaran operasional yang dikeluarkan oleh kasir untuk mendukung kegiatan perusahaan sehari-hari.

b) Laporan Pembelian

Gambar 26 merupakan laporan pembelian pada CV Mitra Karya pada distributor/supplier yang telah diinputkan dan divalidasi pada system, sehingga dapat mendapatkan laporan pembelian per nota pembelian yang telah tercantum pada nota pembelian dari distributor/supplier

c) Laporan Kas

Gambar 27 merupakan halaman laporan kas yang merupakan rekapitulasi keuangan masuk maupun keuangan keluar yang berasal dari transaksi penjualan, pembelian, pengeluaran operasional, serta segala kegiatan transaksional keuangan perusahaan CV Mitra Karya Malang

d) Laporan Stock Opname

Gambar 28 merupakan halaman laporan transaksi stock opname yang merupakan rekapitulasi dari perbandingan stok yang terdapat pada system serta stok yang dihitung pada kondisi fisik (gudang) kemudian untuk dilakukan penyesuaian stok untuk memberikan nilai stok yang valid sesuai kondisi asli pada gudang. Setelah dilakukan konversi atau penyesuaian stok maka dapat dihasilkan laporan stock opname seperti pada gambar 28.

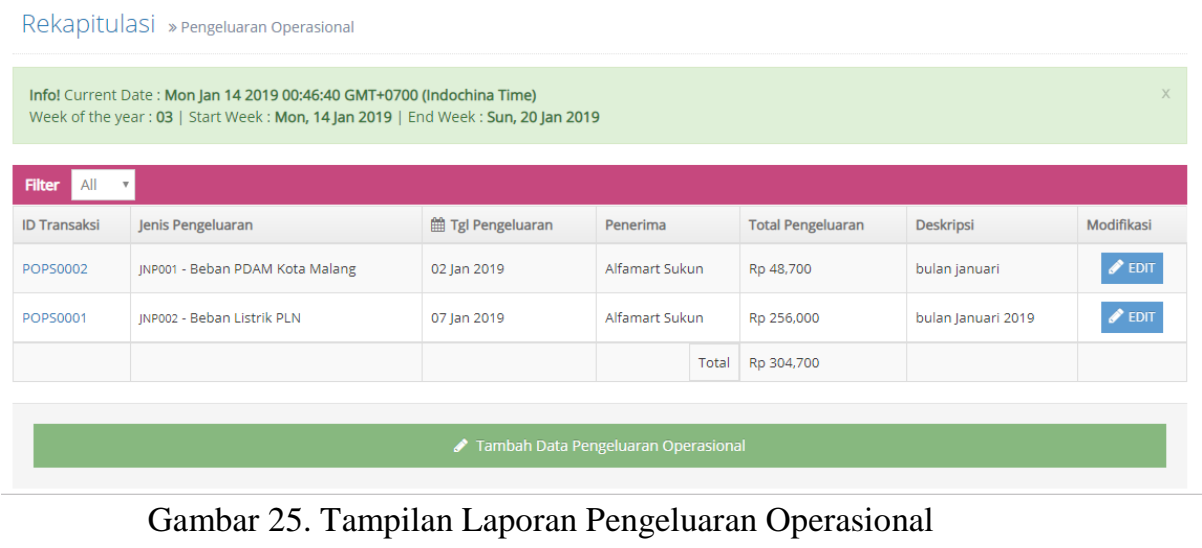




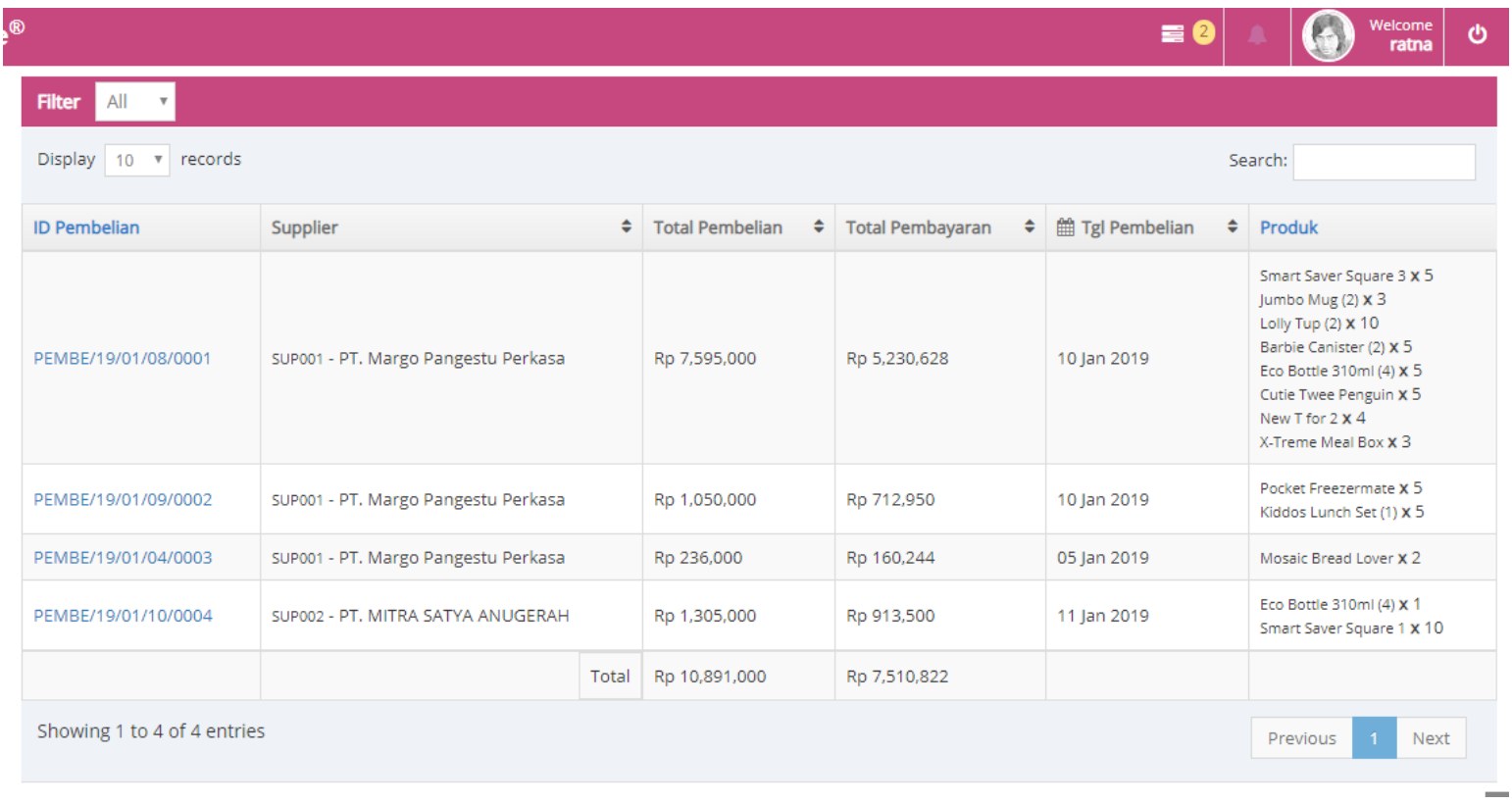

Gambar 26. Tampilan Laporan Pembelian

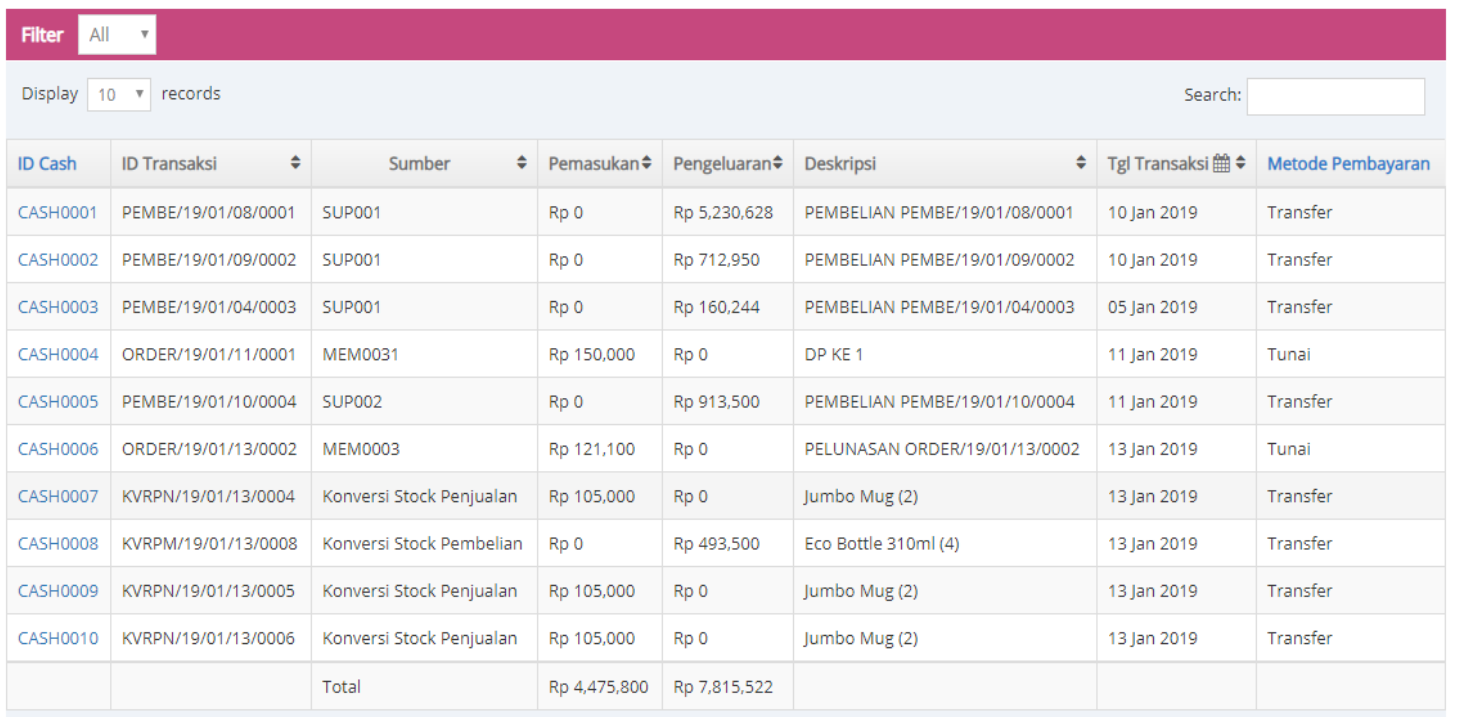

Gambar 27. Laporan Kas

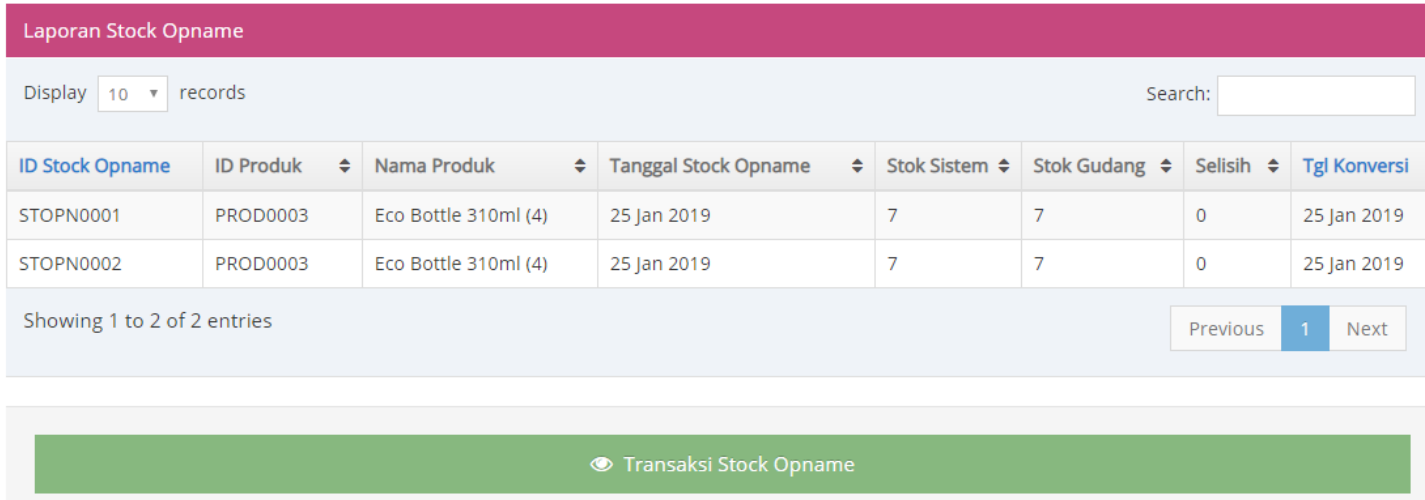

Gambar 28. Tampilan Laporan Stock Opname 


\section{KESIMPULAN}

Sistem informasi manajemen internal perusahaan distributor tupperware pada CV Mitra Karya dibangun dengan metode Three Major Phase, dikembangkan dengan bahasa pemrograman PHP, dan database MySQL. Sistem dikembangkan berdasarkan aturan sistem informasi manajemen dan pengelolaan gudang dan stok produk dengan menyesuaikan kebutuhan bisnis proses CV Mitra Karya.

Sistem ini dapat membantu CV Mitra Karya untuk:

1) Meningkatkan efektifitas data dan transaksi pembelian dalam proses bisnis sehari-hari.

2) Mempercepat proses transaksi, dan meminimalisir kesalahan manusia.

3) Mencatat data paten sebagai master yang digunakan dalam transaksi.

4) Mencatat, mengolah, dan mengkalkulasi transaksi pembelian, retur dan garansi produk dan pengelolaan stok dan produk pada Gudang CV Mitra Karya Malang.

5) Menampilkan laporan pembelian, laporan stok produk, serta laporan keuangan pada periode tertentu.

6) Melakukan kegitan stock opame yang dapat dilakukan berkala guna mendapatkan keakuratan jumlah stok yang berada pada system dan pada kondisi di lapangan.

Saran pengembangan sistem, yaitu Sistem Informasi Akuntansi guna mengelola keuangan perusahaan dengan standar akuntansi, antara lain: Pengelolaan Pemasukan Keuangan (Penjualan), Pengeluaran Perusahaan (Pembelian dan Pengeluaran Operasional), Laporan Kas, Neraca Saldo, Neraca Rugi Laba, Neraca Akhir

Karena pengelolaan Keuangan pada CV Mitra Karya sangat diperlukan untuk mengetahui bagaimana perjalanan keuangan perusahaan, mengetahui pengeluaran dan pemasukan perusahaan hingga dapat menghasilkan laporan keuntungan atau kerugian atas usaha yang telah berjalan pada periode tertentu.

\section{REFERENSI}

[1] Bootstrap 2014, Bootstrap HTML, CSS, and JS Framework, diakses 16 Oktober 2015, $<$ http://getbootstrap.com>.

[2] Jogiyanto 2010, Analisis dan Desain Sistem Informasi, Penerbit Andi, Yogyakarta.Knight, K 2011, Responsive Web Design: What It Is and How To Use It, diakses 23 Oktober 2015, <http://www.smashingmagazine.com/2011/01/12/guidelines-for-responsive-webdesign $>$.

[3] MADCOMS 2011, Dreamweaver CS5 dan PHP MySQL Untuk Pemula, Penerbit Andi Offset, Yogyakarta.

[4] Wikipedia 2015, Entity Relationship Diagram, diakses 10 September 2015, <http://en.wikipedia.org/wiki/Entity-relationship_model>.

[5] Marakas, George A., dan James O’Brien 2012, Introduction to Information System, 15th Revised Edition, McGraw Hill Higher Education, New York City.

[6] Tupperware Indonesia 2018, Jenjang Karir Member Tupperware, diakses 27 September 2018, <https://www.tupperware.co.id/karir/jenjang-karir>

[7] Jual Aku.com 2018, Pendapatan Star Chart dan Kupon pada Member Tupperware, diakses 28 September 2018, <http://juallaku.com/cara-daftar-member-tupperware-2017/>

[8] Cahyodi, Sapto Caturd., dan Rita Wahyuni Arifin 2017, Sistem Informasi Point of Sales Berbasis Web Pada Colony Amaranta Bekasi, Manajemen Informatika; STMIK Bina Insan, Bekasi Timur, Indonesia

[9] Fikri Haris 2016, Activity Diagram, diakses 03 Oktober 2018 <https://www.academia.edu/26265553/Activity_Diagram_Diagram_Aktivitas_UML_?aut $\mathrm{o}=$ download $>$ 
URL : https://jurnal.machung.ac.id/index.php/kurawal

[10] Martin Records.com 2018, Web Browser, diakses 11 Oktober 2018 $<$ http://www.martinrecords.com/technology/pengertian-web-browser-sejarah-fungsi-sertacontohnya/

[11] Ahmad Udin \& Dedy Rahman Prehanto 2016, Rancang Bangun Sistem Informasi Pengelolaan Keuangan Zis Masjid Berbasis Web, Manajemen Informatika, Teknik Informatika; Fakultas Teknik, Universitas Negeri Surabaya, Jawa Timur, Indonesia

[12] Tri Sulistyo, Rancang Bangun Sistem Penjualan Berbasis Web Pada Perusahaan Pro Design Art and Gallery Semarang, Teknik Informatika; Universitas Dian Nuswantoro, Semarang, Jawa Tengah, Indonesia 